\section{Don't underestimate the death rate from Chernobyl}

SIR — Your News story "Chernobyl: poverty and stress pose "bigger threat' than radiation" (Nature 437, 181; 2005) suggests that the health and environmental effects of the Chernobyl accident were not as great as originally suggested.

Writing on behalf of an international group of researchers in this area (see http://cricket. biol.sc.edu/chernobyl/nature/letter.pdf), we believe that these suggestions, based on the reports of the UN Chernobyl Forum, are misleading.

\section{"As we approach the twentieth anniversary of the Chernobyl disaster we should be sensitive to the long-term implications." - T. A. Mousseau and colleagues}

The full estimate, given by the UN report, of people who could eventually die of factors linked to radiation includes people in other contaminated areas as well as those within Soviet Contaminated Zones and is 9,335, not 4,000 as reported. This estimate is similar to earlier estimates of future cancer mortality prepared by the US government in December 1987 (Report on the Accident at the Chernobyl Nuclear Power Station, US Nuclear Regulatory Commission, Washington DC). Further details to support our argument that neither of these estimates should be downplayed are available at the website above.

We believe it is too early to assess the overall impacts of radionuclide exposure on human health or on plant and animal populations. In particular, we do not know all the possible consequences of the multigenerational accumulation of genetic defects. As we approach the twentieth anniversary of the Chernobyl disaster we should be more sensitive to the long-term implications rather than suggesting that the coast is clear for redevelopment in the contaminated zones.

Up to now, most studies have focused on cancer, because of funding constraints, with little investment in studies of non-cancer morbidity or model systems. But model organisms with relatively short lifespans may provide a clear picture of the multigenerational consequences for human health, while humans exposed to Chernobyl are a unique population that must be supported and observed far into the future.

Given the long latency period for many diseases and the growing interest in rejuvenating the nuclear power industry, it is imperative that studies of the affected populations continue.

Timothy A. Mousseau ${ }^{\star}$, Neal Nelsoni, V. Shestopalov

*School of the Environment,
University of South Carolina, Columbia, South Carolina 29208, USA

†102 Ashton Birch Drive, Springfield, Virginia 22152, USA

†Radioecology Centre of the Ukrainian National Academy of Sciences, Kyiv 01054, Ukraine

\section{Media reports: call for a working party is unrealistic}

SIR - The call, made in your Editorial "Responding to uncertainty" (Nature 437, $1 ; 2005$ ), for learned societies to create fast-acting working parties to respond to sensational news stories arising from journals, is unrealistic in the United Kingdom.

Having worked in and with UK biological learned societies for a couple of decades, including a term as a member of the Council for the Association of Learned and Professional Society Publishers, I can testify that the vast majority simply do not have the resources to implement this suggestion. Further, their members have full-time commitments and so would find it difficult to attend such working parties at short notice.

The best that might be achieved would be for those societies that publish journals to call upon their editorial boards to justify the decision to publish, and to clarify any uncertainty arising out of media reporting. However, even this would not be applicable to all cases: for instance, the example you cite of the MMRvaccine would not be covered as The Lancet is produced by a publishing house and not a learned society.

Jonathan Cowie

Science-com.concatenation.org

Northumberland Heath,

Kent DA8 3EU, UK

\section{Main effect of bureaucracy is to reduce productivity}

SIR - Your News Feature ${ }^{\alpha}$ The nightmare before funding" (Nature 437, 308-311; 2005), on the horrors of writing grant applications, will strike a chord with researchers everywhere.

To my knowledge there has never been any objective analysis to determine whether or not increasing the complexity in the funding process has improved decision-making by the funding agencies or produced higherquality research from the recipients of the funds. The only outcome of which we can be certain is that the wasted time makes grantwriters less productive. This in turn means that, for those agencies that burden us with this administrative nonsense, the science base is less competitive. I know this because, in order to keep my own research group running on a relatively modest scale, I have not been able to do an experiment for five years, and I am certainly not alone.

The pessimistic view is that we are now too bogged down in this mess ever to return to a simpler, more sensible way of doing things. I tell my $\mathrm{PhD}$ students that the allure of research used to be the intellectual challenge, but nowadays you'd better be up for the administrative challenge too.

Stephen Moss

Ashton Chair of Biomedical Research,

Division of Cell Biology,

Institute of Ophthalmology,

University College London,

11-43 Bath Street, London ECIV 9EL, UK

\section{Concern at animal research should not be dismissed}

SIR - Your Editorial “Still not deterred" (Nature 437, 1-2; 2005) calls on universities to support animal research. We are all horrified at the techniques of the terrorists, but the much wider public is increasingly sceptical about animal research. These are legitimate concerns that should not be dismissed because of a few fringe characters. As scientists, we depend on public funds, so we are under an obligation to explain why animal research is morally acceptable.

We argue that animal research can yield information not available through other experimental techniques. Historically, we have experimented on slaves and prisoners. Given that we can no longer justify the suffering of human research subjects, even if it could save lives, how can we accept the suffering of animal research subjects? We must recognize that the decision to experiment with animals is a moral decision, not a scientific one. Our society does not believe that the end justifies the means. Do we disagree?

Our contention that humans are unique among the animals is a religious argument. As an evolutionist, I find it absurd to think that human culture and society developed without precedents among animals. We in fact now have evidence for animal cultures, as reported in the pages of this journal.

Perhaps we need to come up with better arguments - or better experiments that don't offend the public.

Jacqueline Zupp

CCBC - F520, 7201 Rossville Boulevard, Baltimore, Maryland 21237, USA

Contributions to Correspondence may be submitted to corres@nature.com.They should be nolonger than $\mathbf{5 0 0}$ words, and ideally shorter. They should be signed by no more than three authors; preferably by one. Published contributions are edited. 